UDC 339.13

DOI: https://doi.org/10.32782/2224-6282/167-2

Filon Mykhailo, Borsuk Yevheniia South Ukrainian National Pedagogical University named after K. D. Ushynsky

Філон М. М.
кандидат економічних наук,
старший викладач кафедри політичних наук і права,
Південноукраїнський національний педагогічний університет
iмені К. Д. Ушинського
ORCID: https://orcid.org/0000-0002-2131-6413

Борсук С.Г.

студентка,

Південноукраїнський національний педагогічний університет імені К. Д. Ушинського

\title{
THE INFLUENCE OF COLOR IN ADVERTISING ON THE PURCHASING POWER OF CONSUMERS
}

The article considers advertising and its colors. A study of the impact of color on the purchasing power of consumers on the example of well-known nonsense that is popular for Ukrainian buyers, advertising and its color scheme, the impact of color on the purchasing power of consumers. Perception of color and emotional attitude to it depends mainly on the emotional state of man and the associations they arise. Certain emotional states of a person correspond to his attitude to color, shade and combination of colors: one color is preferred, another does not cause special emotions, the third is completely rejected. And also it is possible to note about age features of the relation to color scale.

Keywords: advertising, color scheme, brand, purchasing power, marketing activities.

JEL classification: Z10, Z13, Z19, Z33

\section{ВПЛИВ КОЛЬОРОВОЇ ГАМИ В РЕКЛАМІ НА КУПІВЕЛЬНУ СПРОМОЖНІСТЬ СПОЖИВАЧІВ}

Реклама є основним та найважливішим процесом інформування суспільства, що має психологічний вплив на людину. Реклама тим чи іншим способом впливає на споживача. I важливу роль відграє абсолютно все: період в який була розміщена реклама, простір, форми які вжито, текст, шрифт, стиль, фон, зображення $і$ колір. Всі ми ие добре розумісмо, але не завжди можемо дати логічне пояснення нашому вибору. У статті проведено дослідження впливу кольорової гами на купівельну спроможність споживачів на прикладі відомих бреднів, які популярні для українського покупия, розглядається реклама та їі кольорова гама, вплив кольору на купівельну спроможність споживача. Термін "реклама" походить від лат. reclamare - викрикувати. Сьогодні реклама є найдієвішим засобом впливу на покупиів і споживачів. Існують різноманітні визначення і тлумачення поняття реклами, щчо аналізуються у цій статті. Для ефективної реклами дуже важливо правильно підібрати світло $і$ колір. Психологи вважають, щзо світло кидає виклик людині, закликає його до дї. Відтінки освітлення викликають у людини різні настрої. Колір в рекламі набуває особливого значення завдяки своїи здатності впливати на настрій споживачів. Колір оживляє, дратує, спонукає до співпереживання, викликає асоціації з пропонованим образом, сприймається простіше та діє безпосередніше, ніж форма. Таким чином, будь-яка реклама впливає на споживача своєю кольоровою гамою. Сприйняття кольору $і$ емоційне ставлення до нього залежить головним чином від емоційного стану людини та асоиіацій, які вони виникають. Можна сміливо зазначити, що певним емоційним станам людини відповідають його ставлення до кольору, відтінку та поєднанню кольорів: одному кольору віддається перевага, інший не викликає особливих емоцій, третій зовсім відкидається. А також можна зазначити про вікові особливості відношення до кольорової гами.

Ключові слова: реклама, кольорова гама, бренд, купівельна спроможність, маркетингова діяльність.

Formulation of the problem. Today, advertising is the main and most important process of informing society, which has a psychological impact on people. We all know that advertising affects the consumer in one way or another. And everything plays an important role: the period in which the advertisement was placed, the space, the forms used, the text, the font, the style, the background, the image and the color. All this makes advertising holistic and harmonious in the eyes of the consumer and is deposited in the subconscious. We all understand this well, but we cannot always give a logical explanation for our choice. Going to the store, we choose a product without even thinking: "Why did we choose it?".

Analysis of recent research and publications. In general, interest in the theoretical understanding of advertising and purchasing power has grown significantly with the development of scientific and technological progress. Various aspects of this issue are reflected in the works of such scientists as N.Yu. Butenko, R.V. Kovalenko, F.G. Pankratov, L.M. Titkova, L.M. Khromov, V.H. Sha- 
hurin, and others. The contribution of foreign scholars, in particular Rosser Reeves, who is the author of unique advertising images and slogans, is very significant. The aspects of the impact of color scheme on customers' purchasing power taking into account advertisements of well-known brands are not revealed enough in the research and lack explicitness.

The purpose of the article. Research of the influence of color scale on the purchasing power of consumers on the example of well-known nonsense that is popular for Ukrainian buyers.

Presenting main material. The term "advertising" comes from Latin. reclamare - to shout (in ancient Greece and Rome, announcements were shouted loudly in crowded places). Today, advertising is the most effective means of influencing buyers and consumers. There are various definitions and interpretations of the concept of advertising [4].

Advertising is a printed, handwritten, oral or graphic message about a person, goods, services or social movement, openly published by the advertiser and paid to increase sales, expand clientele, gain votes or public support [4].

In Art. 1 of the Law of Ukraine "On Advertising" contains the following definition:

Advertising is special information about people or products that is distributed in any form and in any way for the purpose of direct or indirect profit [1].

Summarizing all the above, we can say that advertising is the main and most important process of informing society about new and very popular products that have a psychological impact on people.

From the point of view of culture it is possible to consider registration of advertising. After all, some commercials, banner signs look like a real work of art. And the main role is played by many factors in the period in which the advertisement was placed, the space, the forms that were used, the text, the font, the style, the background, the image and the color. In the same way, color makes advertising bright and attractive.

It is believed that there are 3 main colors - red, yellow and blue. And the rest of the colors are formed by mixing them. There are millions of mixed colors and shades, the existence and name of which we did not even think about.

It is the selection of these colors and shades for their harmonious use and is called the color scheme. After all, one smallest detail of another color can ruin the integrity of the object. Therefore, it is not surprising that global brands are willing to spend billions on the popularity and recognition of their logos. Sometimes we can name a brand by just one shade of color. So going in public transport, we can see the building with shades of green and even without reading the sign to conclude that it is a commercial bank "PrivatBank".

Such a popular color as green is used not only by this bank, but also by many networks of pharmacies, veterinary clinics, the leading spreadsheet program Microsoft "Excel", "Sprite" and the online store "ROZETKA".

Green is the color of peace and nature, which symbolizes youth, naturalness, resolution, vitality and simply relaxes. Perhaps it is these properties of green that have made brands so popular. After all, the green positive smiley from "ROZETKA" evokes trust and positivit.

For a person, the color red is associated with strength, power, prohibition, initiative, aggression and triggers a strong emotional reaction. He forces to act decisively, which determines why he attracts attention to himself and arouses interest. Some people associate red with passion, love, thirst, blood and death. Therefore, it should not be abused [3].

We can safely say that red is a favorite color, as it is used by many well-known brands. These include McDonald's, a world leader in fast food, Sosa-Sola, the world's largest producer of carbonated beverages, Levi's, clothing brand, Tavria B, an all-Ukrainian supermarket chain, the popular YouTube, and a leading Ukrainian operator. Vodafone, a Ukrainian express delivery company Nova Poshta and the multinational automobile company Mitsubishi Motors Corporation. This list goes on and on.

McDonald's spends more than $\$ 2$ billion annually on advertising. Golden Arches are extremely famous. The use of collectible toys, TV commercials, promotions in schools and characters like Ronald McDonald are aimed at the main group of consumers - children. And the Sosa-Sola logo is considered to be the most famous on earth. Maybe it's all the effect of red on the buyer, but these brands will be at the top of popularity in the market for a long time.

As for blue, it is calm and balanced, it makes you think and makes you concentrate. Does not attract attention, as red color, but at the same time does not repel. It also symbolizes water, movement, freedom and cold. Blue is perceived softer and lighter than blue, but is also associated with calm and harmony [3].

Blue and all its shades are used by the world's largest social network "Reebok", Ukrainian telecommunications company "Kyivstar", "PepsiCo", Ukrainian grocery chain "ATB-Market", Ukrainian retail chain of wholesale hypermarkets "Fozzy" and text editor Microsoft Word.

Yellow is symbolized with pleasant emotions, vitality, positivity, warmth and care. It reminds people of communication, thoughts that you may have - it's the sun or a lemon. So the mood is appropriate: joy, elation, pleasure. The color of an open soul and the desire to communicate [3].

Such a positive and characteristic of color are brands that use it. These include the Snapchab multimedia mobile application, the Spanish company Chupa Chups, the Italian company Ferrari, the Gala washing powder and the worldfamous yellow symbol, the Tahi public transport vehicle.

Orange color brings excitement, joy, stimulates and has a cheerful beginning. It is a loud, hot, fiery, cheerful and cheerful color. It uses the famous soft drink "Fanta", a free free web browser "Mozilla Firefox" and software "Microsoft PowerPoint".

Purple affects concentration. The color itself is associated with creativity and unusualness. You need to carefully and correctly choose shades of purple, because they affect the consumer in quite different ways. If you choose too dark, it will repel, but more gentle on the contrary will please the eye. At the moment, purple is the most popular color when creating a logo for a brand, banner of a popular event or model show. It is also a mystery among other color solutions, associated with nobility, elegance and sophistication. You should be careful with purple, because it is a color that is difficult to combine with any other [3].

The Milka milk chocolate brand and the Viber application program are famous for their purple brands.

The main color in the entire palette, which ranks first in use in advertising is black. It is even used in folk art, so 
in the famous song "Two Colors" by Dmytro Pavlychko it is stated that black symbolizes sorrow. Indeed, many associate it with night, fear, death and mourning. But you should not abuse this color, it is better to use it to highlight details, emphasize the font, or focus on something. Mystery, elegance, nobility - it's all about black. It can be strict or playful, it all depends on the presentation of advertising.

Fans of black are the American company Nike, the German company Adidas, the film company Walt Disney Pictures and the French company The House of Chanel.

Not the main, but an auxiliary color in advertising, as black can be distinguished and white. For many consumers, it is associated with purity, transparency, honesty, uncertainty and emptiness. Most often, white acts as a background. Does not cause much emotion, as the consumer is neutral to him, but good if you want to convey information. It is used by many world brands that have been mentioned before, such as Colgate, Ukrainian telecommunications company Kyivstar, Coca-Cola and others.

We would also like to highlight the brands that use a colorful palette for their logo, the American public multinational corporation "Google", the online advertising platform "OLX" and the social network "Instagram".

It should be noted that we have identified the most famous and popular brands for the Ukrainian consumer.

From a psychological point of view, effective advertising should be a positive emotionally colored assessment of goods and services, which the advertiser communicates to consumers [2]. For effective advertising it is very important to choose the right light and color. Psychologists believe that light challenges a person, calls him to action. Shades of lighting cause a person different moods. Color in advertising is especially important due to its ability to influence the mood of consumers. Color invigorates, irritates, encourages empathy, evokes associations with the proposed image, is perceived more simply and acts more directly than form. It does not need to be interpreted as words. Impressions inspired by color are very stable [3].

Therefore, world-renowned companies are willing to spend billions to increase demand for their products, focusing on colors. As mentioned above, it is not possible to win the favor of buyers with one color. This should be done in color. After all, in this case, colors and shades complement each other and create a holistic picture.

You also need to pay attention to the importance of color for humans. Color has an associative character and inspires a person with certain emotions and memories. This does not mean that you need to create an ad color scheme based on your own associations. To get started, you need to get to know your working audience. After all, children perceive colors differently, and the elderly prefer calmer colors and shades.

Conclusions. From the study we can conclude that any advertising affects the consumer with its colors. Perception of color and emotional attitude to it depends mainly on the emotional state of man and the associations they arise. It is safe to say that certain emotional states of a person correspond to his attitude to color, shade and combination of colors: one color is preferred, another does not cause special emotions, the third is completely rejected. And also it is possible to note about age features of the relation to color scale.

Also, some colors in advertising have an advantage in the market for consumers, this list can safely be attributed to red, blue and green. Black and white are colors used by almost all companies and brands. Because these colors are easier to combine and use to accentuate certain elements. Colors such as yellow, orange and purple are less commonly used, but they are quite accurate and unusual when properly combined with other colors and shades.

Given all the peculiarities of the use of color and color scheme in advertising, their emotional and associative impact on the consumer, we can safely say that the advertising campaign will be successful.

\section{References:}

1. Law of Ukraine "On Advertising" of July 3, 1996 № 270/96-VR. Available at: https://zakon.rada.gov.ua/laws/show/270/96$\% \mathrm{D} 0 \% \mathrm{~B} 2 \% \mathrm{D} 1 \% 80 \#$ Text

2. Butenko N.Yu. (2005) Social psychology in advertising. Kyiv, 250 p.

3. Psychology of color in advertising. Available at: https://leosvit.com/art/psyhologiya-koloru-v-reklami.

4. The essence of the concept of "advertising" and its meaning. Available at: https://studopedia.info/ukr/1-478.html.

\section{Список використаних джерел:}

1. Закон України «Про рекламу» від 3 липня 1996 року № 270/96-BP. URL: https://zakon.rada.gov.ua/laws/show/270/96$\% \mathrm{D} 0 \% \mathrm{~B} 2 \% \mathrm{D} 1 \% 80 \#$ Text.

2. Бутенко Н.Ю. Соціальна психологія в рекламі. Київ, 2005. 250 с.

3. Психологія кольору в рекламі. URL: https://leosvit.com/art/psyhologiya-koloru-v-reklami.

4. Сутність поняття реклама та іï значення. URL: https://studopedia.info/ukr/1-478.html. 